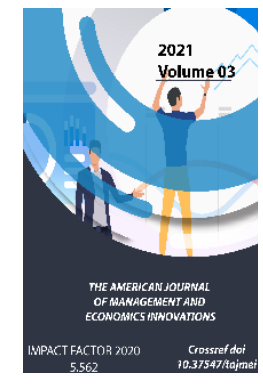

Journal Website: http://theamericanjour nals.com/index.php/taj mei

Copyright: Original content from this work may be used under the terms of the creative commons attributes 4.0 licence.

\section{Analysis Of The Use Of Marketing Tools At The Current Stage Of Development Of The Banking Services Market}

\author{
Sharipova Umidakhon Adkhamovna \\ University Of World Economy And Diplomacy Head Of The Department "International \\ Finance And Investment", Uzbekistan \\ Azimova Gulnoza Latifovna \\ Doctoral Student University Of World Economy And Diplomacy, Expert Of Small Credits \\ Department Of "Kapitalbank", Uzbekistan
}

\title{
ABSTRACT
}

In order to understand the success of the world banks, we will analyze the marketing tools used by foreign specialists in the field of banking. At the same time, it is necessary to define the concepts of "bank marketing" and "bank marketing tools". Bank marketing is the process of regularly improving and improving the efficiency of the bank's activities with the help of a certain set of tools within the framework of the interaction marketing concept and taking into account the market strategy based on the opinion, preferences and needs of consumers.

\section{KEYWORDS}

Marketing, innovation, product, modern technologies, resource, banking services, client, terminal.

\section{INTRODUCTION}

Bank marketing tools are a set of techniques and actions aimed at meeting the needs of customers in banking products or services.

In the era of the development of Internet technologies, it is becoming increasingly difficult to maintain a leading position in the banking services market. Innovations introduced by banks have become one of the most important means of attracting potential customers.

On May 14, 2018, the President of the Republic of Uzbekistan signed a decree "On measures for the accelerated development of ecommerce". The document approved the Program for the development of e-commerce in the Republic of Uzbekistan for 2018-2021. 
The resolution notes the problems and shortcomings that " prevent the creation of a full-fledged e-commerce market in the country, the unhindered access of goods and services of domestic manufacturing enterprises to foreign markets."

Already today, there are successfully functioning means for paying for services online, such as Uzcard Click, mBank, SmsTolov. People can make purchases from the comfort of their homes in online stores, including: Mytech.uz, Esavdo.uz, Arba.uz, Gifty.uz, Uzbekmarket.uz, Avtech.uz Uzbekmarket.uz, Bozor.uz and others where you can buy food, clothing, appliances, perfumes, household goods and even furniture.

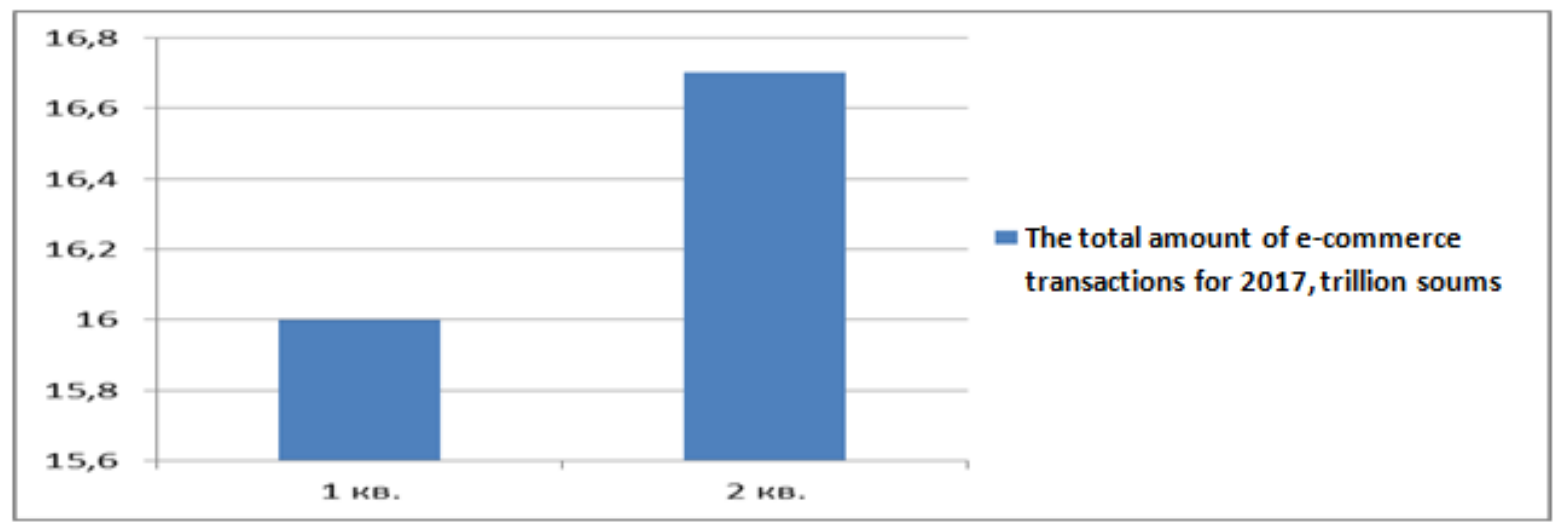

Website:https://www.spot.uz//2018/06/25/e-commerce/

According to the unified Republic processing center (EOCC), the final data on e-commerce show a steady increase in the number of ecommerce transactions in Uzbekistan in the 2nd quarter of 2017. As a result, the number of e-commerce operations was 89,5 million, of which $3,6 \%$ more than in the same period of the previous quarter, 86,4 million transactions were recorded. In the 2nd quarter of 2017, the total volume of e-commerce operations amounted to 16.7 trillion. compared to the same period last year $4,4 \%$ more -16 trillion. made up the sum. 


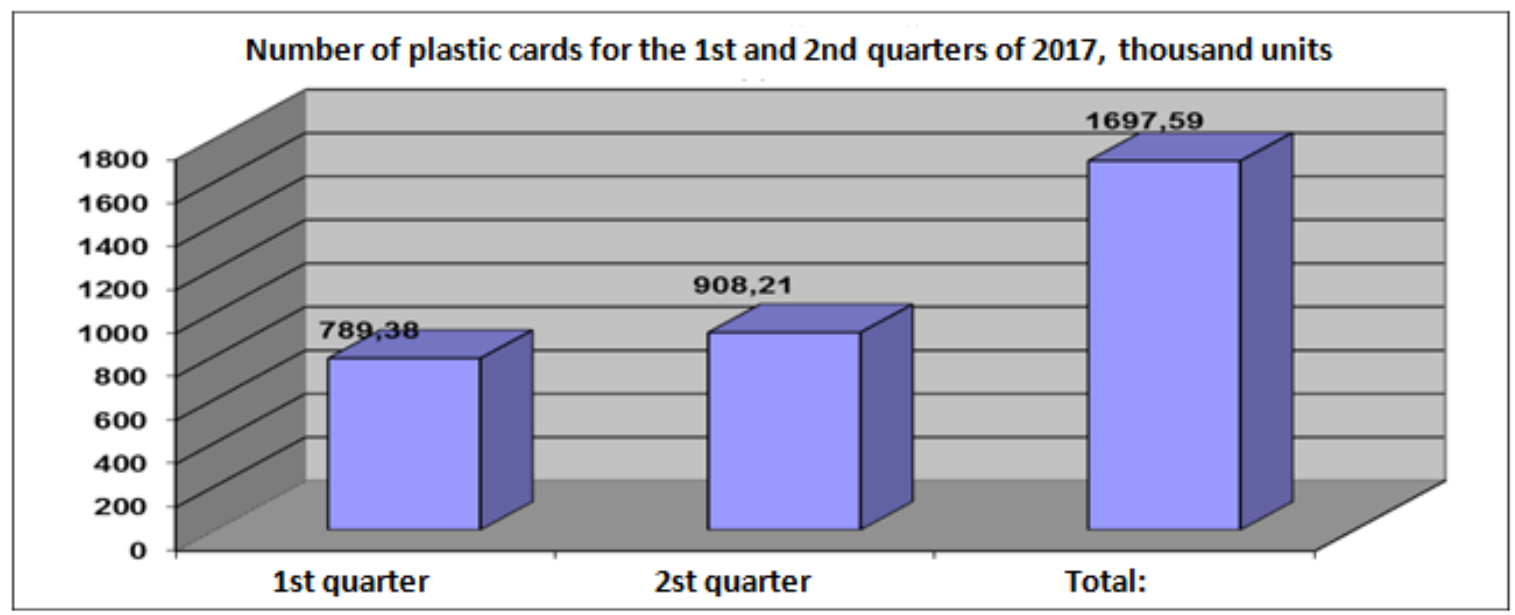

Website:https://www.spot.uz//2018/06/25/e-commerce/

The market potential is $\$ 1.2$ billion. This includes the sphere of services in particular and banking services, the sphere of goods, delivery.

Currently, it is difficult to find a bank that does not apply innovations and modern customer service technologies in its business strategy. However, despite this, many experts believe that one of the reasons for the financial crisis is the introduction of innovations in the banking sector that did not interest the consumer. It should be taken into account that customers and banks perceive the concept of "innovation" differently. Therefore, when developing a new innovative product or service, the bank should carefully analyze the preferences and needs of a potential client.

Working with specific audience segments on the Internet is a distinctive feature of foreign retail banking. One of the most effective tools is microsites created in accordance with the specifics of the target audience and "speaking" the same language with a potential client, as well as meeting his specific needs. For example, Bank of America confidently holds the first place in the market among US students for two banking products - checking accounts and credit cards.

Bank of America's online project aimed at college students is called Morris on Campus. Life According to an Upperclassman (Morris on campus.Life after school). Young people are an extremely valuable category for Bank of America. If it is possible to attract the attention of students, then it is likely that they will not just open their first accounts, but also stay with the bank for life.

The next example of the foreign practice of attracting customers is the launch by the English bank NatWest of a new online tool that helps parents plan future family expenses. According to statistics, in the UK, the maintenance of a child from birth to 17 years costs parents on average about 307,083 f. st. Such a high cost may surprise many future parents and encourage them to accumulate the necessary amounts, bankers 
say. Thus, the bank can attract a new group of clients - young parents.

The presence of banks not only on the Internet, but also in social networks is causing more and more heated discussions. In a study conducted by MSR Group in 2013, it was claimed that only $2 \%$ of foreign consumers of online banking services intend to constantly monitor the information published by their financial and credit organization in social networks.

For example, many global banks constantly tell their clients about new products and services on social networks, as well as engage in financial education of the population. Interaction through social networks can be very profitable for the consumer, since sometimes they learn about profitable offers only from there.

Digitalization of the banking sector is a complex and complex process. But its ultimate goal is clear and simple - to save resources (time and money) for both customers and banks themselves.

How it looks to the user:

банк the bank is available at any time via any channel convenient for the client: a bank office, a call center, video communication, an ATM, mobile and Internet banking, chatbots, social networks and messengers; клиент the client forgets the way to the bank's office, because he can get any service remotely: open a card with its delivery to his home, apply for a loan, open a deposit, and so on;

The service becomes more personalized, up to individual tariffs. All thanks to big data, using which banks know so much about customers that they themselves offer services without waiting for a request.

A classic example of a digital bank is the Russian Tinkoff Bank, which does not have a single office. Its main channels of interaction are a website and a mobile application through which you can order a card (it will be delivered to your home for free), apply for a loan (including cash, which will also be delivered to the client) or a deposit. Customers can top up the card or withdraw cash through ATMs, and all communication takes place through digital channels.

Today, the main trend affecting the promotion of banking services in Uzbekistan is the digital transformation of banks. The first digital bank in Uzbekistan will be a foreign company - TBC Bank Group PLC, which at the end of April received a license from the Central Bank for the right to operate in the country. 


\section{Number of users of remote maintenance systems in the Republic of Uzbekistan (in thousands) \\ (as of January 1)}

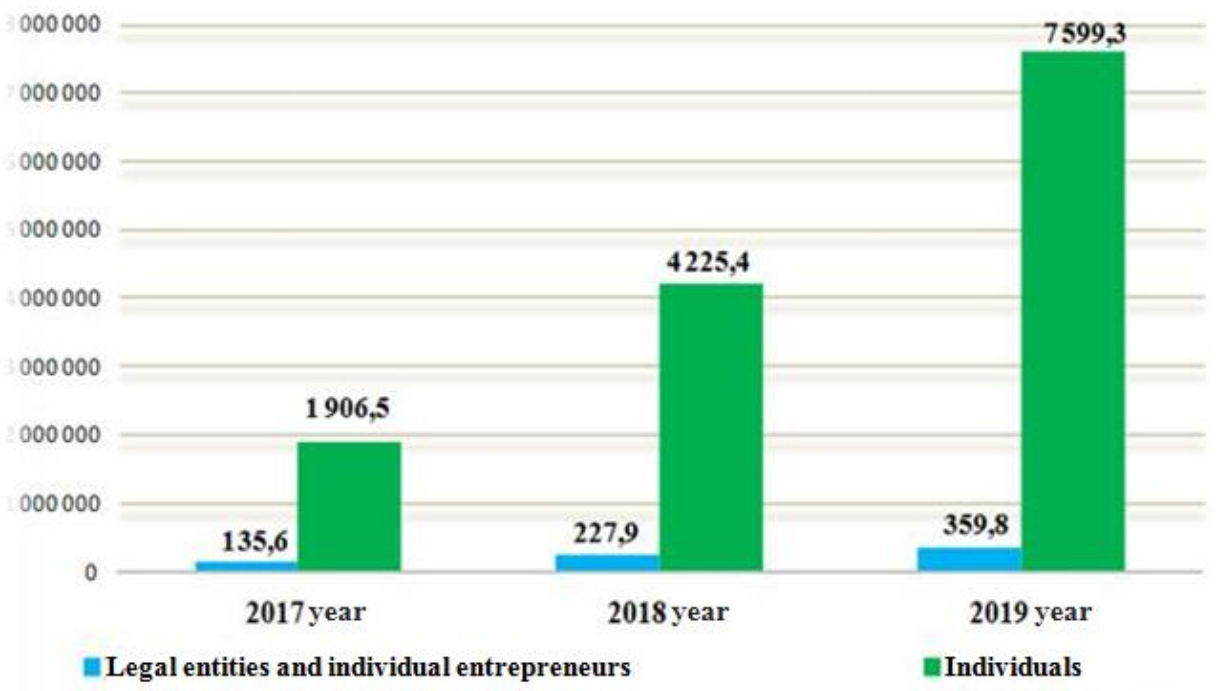

In the reporting year, commercial banks of the republic continued to work on the development of non-cash payment systems using bank plastic cards. For this purpose, the network of payment terminals, ATMs and information kiosks installed at trade and payment services facilities has been expanded.

As of January 1, 2019, there are 17,686 thousand bank plastic cards in circulation, due to the closure of the DUET plastic card system, the total number of cards in use has decreased.

As of January 1, 2019:the number of payment terminals $-244,913$ pcs., there was an increase relative to the state as of January 1, 2018 (235,712 pcs.) by 3.9\%;the number of ATMs and information kiosks - 6,589 pcs., an increase relative to the state as of January 1, 2018 (5,632 pcs.) by $21.8 \%$

The bank's branches, the number of which will be three by the end of the year, will differ from traditional bank offices. They will be more like

Apple stores, where the emphasis is on selfservice.

Preliminary permission to create a digital bank was also received by Anor Bank, whose founders, according to the Telegram channel Bankers.uz, the speakers are natives of the board of one of the largest private banks in the country. So, already in 2021, two digital banks can start working in Uzbekistan at once.

Uzbekistan began to take the first steps towards digitalization of the banking sector at the beginning of 2018. Then, at the legislative level, they approved a course for the introduction and development of digital banks. A few months later, online deposits became available to users (they were first introduced in Hamkorbank), then it became possible to convert currency through a mobile application. 
Now the functionality of applications is much wider: you can remotely not only open a deposit and change the currency, but also apply for a loan, order a card, transfer funds to a card, receive a money transfer, manage accounts, pay for goods and services.

However, a full-fledged digital transformation of the sphere has not yet occurred. The level of digitalization of the sector is still low. Banks are still at the beginning of the road and are still far from recognizing them as digital. Despite the fact that almost all banks in the country have got mobile applications, and some even two (for individuals and legal entities), most of them are the formal implementation of the decree "from above".

The country's banking system is characterized by a high concentration: more than $80 \%$ (now $85 \%$ ) of banking assets are in the hands of the state. This explains the fact that until they are told from above, banks will not independently look for new ways of development.

There is an increase in the activity of stateowned banks on the market. The state policy pushes state-owned banks to be more competitive in the market, to maximize profits.

In addition, the government intends to sell state shares in some companies to investors — in such conditions, the bank needs to pay attention to the quality of the portfolio, the customer base, profitability and other indicators.

The emphasis of banks with a state share, including, has shifted towards servicing individuals. Following the private ones, they are trying to make their products and services more accessible and easy to use.

Over the past few years, the banking sector in Uzbekistan has made a breakthrough in development. Most banks began to offer their products and services through digital channels, mobile applications have become more convenient, their functionality has significantly expanded. And in general, banks have finally paid attention to the retail sector and to our citizens as consumers of banking services.

However, not everyone turns out equally well. As a result, you have to receive remote services declared as remote services at the bank's office, most applications have low ratings in Google Play and the App Store, because in addition to failures in the operation of individual products, the entire system can fail: this often happens due to an update, after which users can not even log in to the application. Chatbots created for more rapid interaction with the client respond for several hours, if they give an answer at all.

So, everything is back to normal: to get information, you have to call the contact center and wait for a long time for the operator's response, to perform a simple operation like replacing a card, you need to go to the branch where this card was issued, wait in line there, and sometimes suffer slow and rough service.

However, there are also examples of fairly successful implementation of digital solutions, including mobile applications, for example, Kapitalbank'sApelsin, NBU's Milliy, 
Promstroybank'sJoyda, InfinBANK, IpakYo'li Mobile, Hamkor Mobile and others.

Moreover, banks are increasingly making applications available not only for their customers. This is how the banking sector will win back the market share that was captured by payment organizations such as Payme, CLICK, Upay and others.

Previously, payment aggregators served more than $50 \%$ of card transactions in the national currency by processing payments from cards. Now the banks have "woken up" and began to return this business to themselves. Aggregators can no longer develop if they do not become banks, as they are sorely lacking in currency exchange and credit operations, integration with international transactions.

Due to the rapid digital development of the banking sector over the past two years, payment organizations are losing their positions on all fronts.

All new products and services appear first in banking applications, for example, contactless card reading, anyzany payments, " Yandex.Wallets" and more. In addition, due to specific banking services, such as conversion, online deposits, money transfers, card delivery and lending, banks have a competitive advantage, which ensures a constant flow of customers to banking applications.

For the bank, digitalization is primarily an opportunity to optimize costs:

More than 5,000 people have opened deposits online. This means that the bank saved 5,000 deposit books, did not print out the contract in duplicate and the cash receipt order, the employee did not spend 15 minutes of time opening each deposit and does not spend 5 minutes on paying interest on them every month, the accountant and the cashier did not participate in this operation and also saved 2-3 minutes of their time. A simple calculation shows how many man-days the bank has saved. If you add to this other operating expenses that the bank incurs when servicing each client, you will get a tidy sum.

Internal optimization of the bank also includes digitization of all business processes. For example, the introduction of a credit pipeline, which allows you to make a decision on approving or rejecting a loan application in a few minutes without the participation of a bank employee.

Here, too, two technologies that are leading the digital transformation of the banking sector come into play - big data and artificial intelligence. Having information about the client's income, the number of overdue loan payments and other data, the system analyzes in a few minutes and gives a positive or negative answer, or calculates the optimal interest rate for a certain applicant.

For example, in Kapitalbank, when scoring (automatic assessment of a client's creditworthiness based on data about him), there are elements of big-data. But for now, the bank is limited to its own customer base. Really big data is used by mobile operators who have information about the movement of subscribers: where they live, what restaurants they visit, how often they go on business trips, and so on. In Ukraine, for example, scoring 
takes into account even the contacts of a potential borrower. If he often communicates with people from the bank's blacklist, then the level of risk for this client increases. In Uzbekistan, mobile operators do not provide geoanalytics yet. Therefore, the bank enriches the database at the expense of its own sources.

According to the deputy chairman of Uzpromstroybank, now customer data is scattered in the processing, transaction and other systems of the bank. A project has been launched to create a corporate data warehouse that will collect all the data about the client around it. At the second stage, data showcases are built, based on which you can build analytics and, accordingly, marketing campaigns.

Banks need such an array of information not only to assess the creditworthiness of borrowers. The bank receives and stores a huge amount of information about the client - from his income and the average receipt in the store to the time of card transactions and their location. If you manage this data correctly, you can use it to offer a loan to the client at the right time for him.

The forced isolation of people in the conditions of the pandemic, on the one hand, and the increasing interest of the population in electronic commerce (shopping in online stores, ordering food from supermarkets and food from stores), on the other hand, led to a sharp development of digital banking services.

In particular, it became possible to remotely open a card of national and international payment systems, which the bank's employees delivered to the client at home.

Banks have become bolder to sell their products online and transfer the identification process from the stage of creating an application to the stage of delivering products to the consumer. Internet acquiring, courier delivery, remote scoring, and an unidentified mobile wallet began to develop. After returning to the old life, I think retail services will remain online, as they have shown their viability.

For example, during the quarantine period, Kapitalbank launched remote money transfer and card delivery in just a week. The bank urgently reorganized in all directions: they strengthened the round-the-clock contact center, provided new services to customers, some types of payments, for example, payment by bank details, began to work for free during the quarantine period.

According to the Central Bank, the number of bank cards in circulation exceeds 21 million. At the same time, as of January 1, 2020, more than 10 million people are users of remote banking services. Most of them (93\% or 9.4 million) are individuals.

On the one hand, this indicates the success of the efforts of the banks of Uzbekistan on the way to a fully digital bank, on the other hand, it demonstrates a huge potential for growth.

The entry of a foreign player with ready-made, tested in practice digital solutions will undoubtedly revive the market. 
Two years ago, the exit of TBC Bank to Uzbekistan would have been a disaster for the entire banking retail. Now the banking system of Uzbekistan is already prepared for competition. In general, this is an additional leap in development and an example of improving the customer experience. The population will benefit from entering the TBC bank market, and bank employees will once again think about the slogan " A bank is for a client, not a client for a bank.

Banks that have not started the process of digital transformation now risk being left out in a few years. On the other hand, there are infrastructure problems in the country that do not allow banks to digitalize at a rapid pace. In particular, this is a low level of Internet and smartphone penetration.

Penetration, as well as the cost of mobile and fixed Internet, are the main stop factors for the development of e-commerce. The penetration of smartphones at the level of 40$45 \%$ is also a strong limitation. But in the next 5 years, this picture will significantly improve.

Digitalization also requires regulatory changes.

The key feature of digital banking is the ability to open a bank account without the physical presence of the client. Currently, banks in Uzbekistan do not have such an opportunity, but we expect changes in regulatory documents that will allow opening accounts to customers remotely in the near future, possibly before the end of this year.

In the coming year, the banking sector will undergo strong changes. Professions such as managers selling card and credit products will remain only in textbooks, because the entire retail business will go online.

Utility and one-time payments will be made through the application directly from the sofa, mortgages will be issued from developers, car loans - from dealers, installment cards - in retail chains. People will interact more with the bank through the contact center, mobile platforms and ATMs.

Digitalization helps to save time and resources of the bank's employees and customers. Thanks to digitalization, the cost of all operations has fallen sharply, customers are satisfied with the quality and speed of services — there are only advantages from all sides.

Banks are no longer building buildings, they are expanding server capacities and improving the program code. Because digitalization makes you think carefully before opening a new branch or a mini-bank: isn't it easier to just put a self-service kiosk or an ATM. The expansion of the branch network no longer brings the same income.

98\% of corporate clients have almost forgotten the way to the bank's branches, because all operations are performed remotely.

According to KPMG experts, in the next 10 years, the banking sector will change in a way that has not changed in the last century. It is important that the market is expanding at the expense of players who have become engaged in payments and other banking operations, although this is not a core activity for them. For example, global technology 
corporations like Apple, Google, Samsung already have their own payment services. This makes such large and non-revolving structures as banks become more flexible and customeroriented.

Currently, a promising direction of banking marketing is the introduction of omnichannel customer service in Uzbekistan into banking practice. Omni channel is a form of providing banking services to customers, the task of which is to combine various sales channels, such as websites, mobile applications, social networks, electronic coupons, flash sales, so that a customer or buyer, having started a purchase in a store, can complete it anywhere else using a tablet or laptop.

The study of the omnichannel and the possibilities of implementing this strategy for the development of retail business in the banking sector is the most important, and in some cases the only way to increase the bank's profit, since it allows you to attract an additional number of customers. Given the growing number of Internet users, including in Uzbekistan, this direction of banking business development has great prospects and, if successfully implemented, will allow the bank to expand its market sector, increase brand awareness, and increase the volume of operations.

The Internet as one of the marketing tools attracts banks most of all. This is primarily due to a reduction in costs when performing online operations compared to the costs under the traditional scheme of conducting banking operations. But even this seemingly effective marketing tool has its pros and cons (table. 3.1).

Table 3.1-Advantages and disadvantages of using the Internet in banking marketing

\begin{tabular}{|c|c|}
\hline $\begin{array}{c}\text { Advantages } \\
\text { banking services is reduced }\end{array}$ & Disadvantages \\
\hline Acquisition of a new sales channel as an Internet & Insufficient level of information security \\
\hline On-linecustomerfeedback & $\begin{array}{c}\text { Communication losses due to inconsistency of } \\
\text { data standards }\end{array}$ \\
\hline $\begin{array}{c}\text { The ability to develop new types of products and } \\
\text { services }\end{array}$ & $\begin{array}{c}\text { Additional costs for technical and informational } \\
\text { support }\end{array}$ \\
\hline Round-the-clock access to banking services & $\begin{array}{c}\text { A low percentage of customers who are ready } \\
\text { for this type of service, compared with the } \\
\text { traditional type of service }\end{array}$ \\
\hline $\begin{array}{c}\text { Integration of payment processes with customer } \\
\text { interaction systems }\end{array}$ & $\begin{array}{c}\text { Legal disagreements between the participants of } \\
\text { transactions due to the legal imperfection of } \\
\text { business processes on the Internet }\end{array}$ \\
\hline
\end{tabular}

The analysis of the table. 3.1 data shows that along with the advantages of using the Internet in banking marketing, there are also obvious disadvantages, but they are primarily related to the current state of the banking sector and will eventually be eliminated in the 
process of its development. Also, the marketing tools will be supplemented and transformed over time. Currently, the main task that the bank's management faces is to keep up with the pace of development of the banking market, improve and create its own new technologies for promoting banking products and services.

In addition to the development of the integrated sales strategy (omni channel) in the areas of electronic access, mobility and convenience, the following banking technologies of working with clients are being actively improved and implemented for users in foreign banks:

1) Using deeper knowledge about the client to build a personalized approach, as well as implementing the possibility of using data and interacting with the client regardless of the channels of promotion of banking services in order to attract him on a more emotional level. In this case, the bank will act as an adviser, i.e. offer those products and services that are necessary for a potential client;

2) "Digital" reconstruction of bank branches. With the increasing share of the use of electronic devices among users, banks have a need to change the format of their branches, which are small, built more on the basis of self-service branches, where the main role is played by the use of tablets and video chats on mobile devices;

3) The development of mobile payments. With the advent of new services, such as Apple Pay, mobile payments are now commonplace, but in the field of banking technologies, mobile channels are still poorly integrated with back-office systems (systems for internal accounting of transactions made between the bank and the client). In this regard, it is still difficult for banks to benefit from such a sales channel;

4) Biometric client authentication. Mobile user identification is becoming an increasingly important topic for banks as their customers move from Internet banking to using smartphones and tablets. In particular, Apple Pay has shown a good example-the combination of a fingerprint with tokenization;

5) Development of loyalty programs. According to Finaccord, about 650 million people $(14.5 \%)$ of the world's population participate in at least one loyalty program, and this figure increases by $12 \%$ every year. Banks have already fully appreciated the benefits of this powerful marketing tool. For strategic development, the customer data obtained within the framework of loyalty programs is no less important, allowing you to segment the audience and conduct targeted communication campaigns. Finally, the bank can gain access to the customer databases of other loyalty program participants, as well as retain its own customers interested in accumulating rewards. Given the success of the presented bank marketing tools, it is promising to use them in the promotion of banking services of banks in Uzbekistan.

\section{REFERENCES}

1. Collection of Laws on the activities of banks. Tashkent. "Uzbekistan"2011y.

2. Corporate Code of the Republic of Uzbekistan. T-2016.

3. Alan Wilson "Marketing financial services" Institution of Bankers in Scotland-2006y. 
4. Sobirovna, T. R. (2021). Issues of further improvement of water cadastre legislation of Uzbekistan. ACADEMICIA: An International Multidisciplinary Research Journal, 11(4), 1241-1253.

5. Banking: a textbook. 2nd ed. Pererab.and additional / O. I. Lavrushina. M.: Finance and statistics, 2011. - 594s.

6. Johannes Wernz, 2014, “Bank management and control", ISBN 978-3-642-40374-3.

7. Timothy W. Koch, \&S. Scott McDonald, 2014, "Bank management" 8th edition.

8. N.S Toor\&Arundeep Singh, 2015, "Advanced Bank management" $6^{\text {th }}$ edition, ISBN:8186141855

\section{Internet sites:}

1. www.bma.uz -website of the Financial Banking Academy.

2. www. cbu. uz-website of the Central Bank of the Republic of Uzbekistan. 